Jaurnal of Enviranmental Science, Camputer Science and Engineering \& Technology

An International Peer Review E-3 Journal of Sciences and Technology

\author{
Available online at www.jecet.org
}

Section B: Computer Science

Research Article

\title{
Trade-Off Analysis on Optimization of Fuel Cells and Renewable Energy Sources Softwares
}

\author{
Dr.R.Sagayaraj ${ }^{1}$, Dr. A.Parimala Gandhi ${ }^{2}$, Dr.A.Nazar Ali ${ }^{3}$, \\ Ms.M.Swathisriranjani ${ }^{4}$, Dr. P.Jenopaul ${ }^{5}$ \\ ${ }^{1}$ Professor, Department of Electrical \& Electronics Engineering, Muthayammal \\ Engineering College, Rasipuram, Namakkal 637408 \\ ${ }^{2}$ Assistant Professor (SS), Department of Electronics\& Communication Engineering, \\ KIT-Kalaignar Karunanidhi Institute of Technology, Coimbatore, Tamil Nadu, India. \\ ${ }^{3}$ Associate Professor, Department of Electrical \& Electronics Engineering, Rajalakshmi \\ Engineering College, Chennai 602105 \\ ${ }^{4}$ AssistantProfessor, Department of Electrical \& Electronics Engineering, Muthayammal \\ Engineering College, Rasipuram, Namakkal 637408. \\ ${ }^{5}$ Professor, Department of Electrical \& Electronics Engineering,AdiShankara Institute of \\ Engineering and Technology, kalady, Kerala, India.
}

Received: 12 May 2021; Revised: 31 May 2021; Accepted: 08 June 2021

\begin{abstract}
Fuel Cells will play a significant role among the energy storage devices, and it is one of the vital technical challenges in the present scenario. Various technologies such as Direct Methanol Fuel Cell (DMFC), Hydrogen Fuelled Fuel Cell, Borohydride Fuel Cell, PEM Fuel Cell, Nano-material fuel cell are in vogue for optimizing the energy storage. However, cost-effective PEM-based red-ox flow fuel cell systems are highlighted in this work. In the hybrid system, while integrating the various energy sources, it is challenging to integrate them. Thus, a proper design is required to analyze the techno-economic aspects of integrated renewable energy systems. Hence, this work paves the way to optimize the intermittent nature of various renewable energy sources using simulation software tools such as INSEL, TRNSYS, RETScreen, ARES and HOMER are used for optimizing the maximum
\end{abstract}


efficiency of the fuel cell for photovoltaic applications. This paper also addresses the Trade-Off inference of various software tools available for analyzing the integration of renewable energy sources for sustainable energy development. This work has attempted to optimize the Hybrid Renewable Energy Sources using HOMER software for climatic forecasting. The simulation results of the proposed hybrid system are presented using MATLAB/Simulink software.

Keywords: Renewable Energy, Hybrid Renewable Energy Sources, Hybrid Optimization Model for Electric Renewable (HOMER), Photovoltaic Cells, Fuel Cells, Red-Ox Flow fuel Cell (RFFC).

\section{INTRODUCTION}

China and United States could deploy energy storage more efficiently with advanced, reliable energy storage technologies. In developing countries, renewable energy is crucial in supplying power to remote areas ${ }^{[1]}$. It can also be possible in our country by appropriate design and analysis of fuel cells and enabling fuel utilization as high as $90 \%$ and above. Irrespective of the source, an efficient storage system is complicated for the proficient use of energy. Practical and affordable means to store electrical energy for numerous applications presents a significant challenge for scientists, technologies and engineers. The electrode materials for energy conversion systems, including ionic conducting materials for intermediate temperature fuel cell systems, thorough characterization of the novel materials, aid the fabrication of fuel cells commercially. Energy demand is subsequently increasing due to the increase in population, decreased energy production due to the rise in fuel cost, etc. Among the various energy sources, solar and wind powers are most widely used and predominant ${ }^{[2] .}$

'Hybrid Optimization Model for Electric Renewable (HOMER) is user-friendly, and is used in most of the renowned research laboratories. It uses Visual $\mathrm{C}++$ as a programming language ${ }^{[3]}$. Thus, by using the tool, we can create a system that selects the size of the system's various parameters to give a robust design ${ }^{[4] . ~ I t ~ a l s o ~ d i s p l a y s ~ v a r i o u s ~ t a b l e s ~ a n d ~ c h a r t s ~ a l o n g ~ w i t h ~ g r a p h s ~ w h i c h ~ h e l p s ~ t h e ~ u s e r ~ t o ~}$ compare the multiple configurations and analyse them based on their economic merits. HOMER has fewer disadvantages, including allowing a single objective function for minimizing NPC, does not considering the Depth of Discharge (DOD) of battery, and so on.

\section{MATERIALS AND METHODS}

2.1. Energy Storage Technologies for Fuel Cells: The development and use of fuel cells have experienced rapid growth over the past decades. Fuel cells are electrochemical devices that convert chemical energy stored in a fuel into electrical energy through electrochemical reaction without combustion. However, these sources do not deliver a regular supply easily adjustable to consumption needs. Thus, the need for the study of energy storage in fuel cells as a potential solution.

However, different fuel cells have different types of the electrode such as Direct Methanol Fuel Cell (DMFC), Hydrogen Fuelled Fuel Cell, Borohydride Fuel Cell, PEM Fuel Cell, nano-material based fuel cell in which the discharge of energy can be varied with respect to time. That is why other types of storage technologies are being developed, compared and implemented.

2.1.1. PEMFC: The Proton Exchange Membrane Fuel Cell (PEMFC), also called the solid polymer fuel cell (SPFC) ${ }^{[5]}$, was first developed by General Electric in the United States in the 1960s for use by NASA on their first human-crewed space vehicles. It is mainly used in Aerospace, military and international space station ${ }^{[6]}$. The developments over recent years have brought the current densities up to around $1 \mathrm{Acm}-2$ or more, while at the same time reducing the use of platinum by a factor of over 
100. These improvements have led to a massive reduction in cost per kilowatt of power and improved power density. PEM Fuel cells typically utilize platinum-based catalysts on the Anode to split the Hydrogen into positive ions (protons) and negative electrons. The ions pass through the membrane to the cathode to combine with oxygen to produce water ${ }^{[7]}$. The energy storage in the fuel cell is shown in Fig.1 shows the storing of energy in PEM Fuel cells.

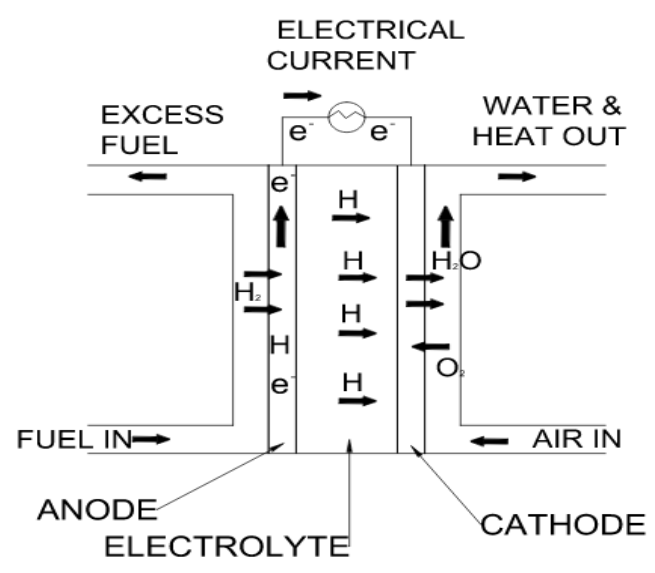

Fig.1: Storage of Energy in PEM Fuel Cell

Each cell generates approximately 1.1 volts, in order to reach the required voltage. Each cell is divided with bipolar plates, and while separating them, it provides a hydrogen fuel distribution channel.

PEM fuel cells are considered to produce highest energy density when compared with the other fuel cells, and due to the nature of the reaction it has the quickest start up time (less than $1 \mathrm{sec}$ ), so they have been favoured for applications such as vehicles, portable power and backup power applications.

2.2. Proposed Work: The storage technologies should meet several requirements such as cost, charging capabilities and performance. In our proposed work we are using Redox technology for stationary energy storage.

2.2.1. Optimization of Energy storage Technologies for fuel cells: Fuel Cells will undoubtedly aid future transportation, which are electrochemical energy conversion devices, which exploit red-ox processes of species in solution in fluid form, stored in external tanks and introduced into the RFFC when needed. In this sense, a polymer electrolyte membrane fuel cell (PEMFC) can be modified into Red-ox Flow Fuel Cell.

2.3. RFFC main features: The principle behind an RFFC cell is a couple of electrochemical reduction and oxidation reactions occurring in two liquid electrolytes (with typical concentrations of $1 \div 5 \mathrm{M})$ containing metal ions $(0.1 \div 9 \mathrm{M}$, strongly depending on the chemistry used). The diagram of proposed work is shown in Fig. 2.

The reduction half-reaction at one electrode extracts electrons and ions from one electrolyte, while the oxidation half-reaction at the other electrode recombines them into the additional electrolyte. Ions migrate from one electrode to the other (from anode-cathode) through an electrolyte that is impermeable to electrons, which are thus forced through an external circuit providing electric energy exchange. In order to keep the solutions in the liquid phase, the cell must operate at near room temperature, for which the ion-conducting electrolyte of choice to be placed between the two 
electrodes is a polymeric membrane. Both half-cells are connected to external storage tanks providing the needed volume of electrolyte solutions circulated by pumps.

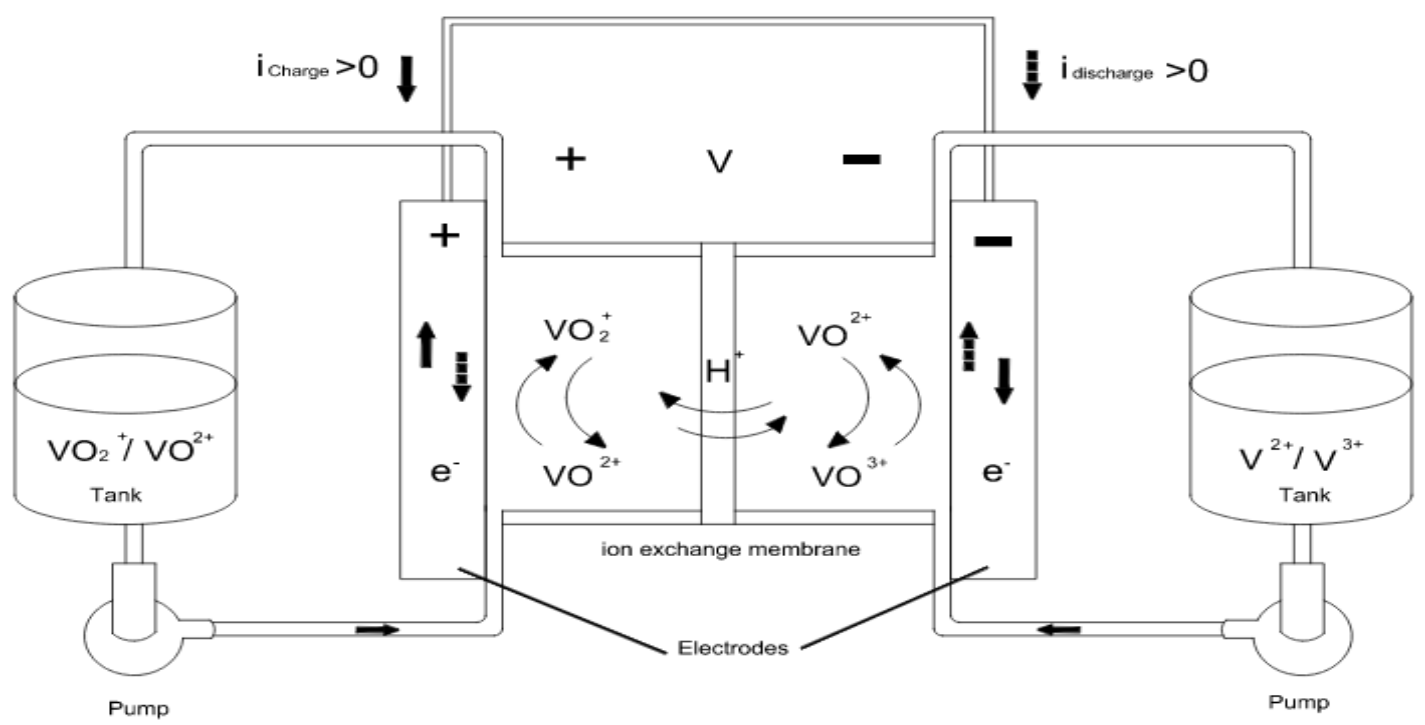

Fig.2: RFFC energy storage system: RFFC stack and electrolyte tanks are separated.

Compared to other electrochemical storage technologies, in RFFCs, as well as in FCs, power conversion is separated from energy storage, thus allowing for independent power and energy sizing. This feature provides for virtually unlimited capacity by merely using larger storage tanks. RFFCs and FCs have more advantages than other electrochemical devices when storage times longer than 4-6 h are required. The arrangement of RFFC with MEA is shown in Fig. 3.

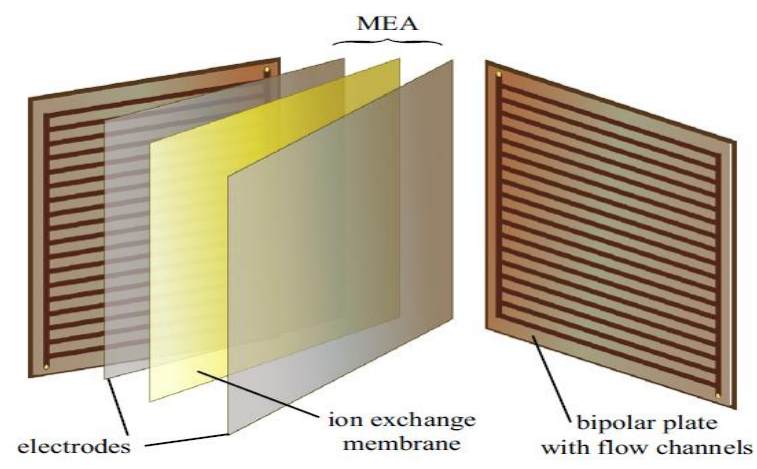

Fig. 3: RFFC with MEA elements and bipolar plates with parallel-channel layout

RFFCs are capable of a rapid response that allows them to span from power quality to energy management services. They can be overloaded over a short period. Moreover, rapid refuelling by solution exchange is possible, in case of need, and furthermore, they require low maintenance.

2.4. Performance Analysis: Similarly to other electrochemical devices, a VRB cell exhibits activation over potential at each electrode when converting energy. The performance analysis is shown in Fig. 4. 


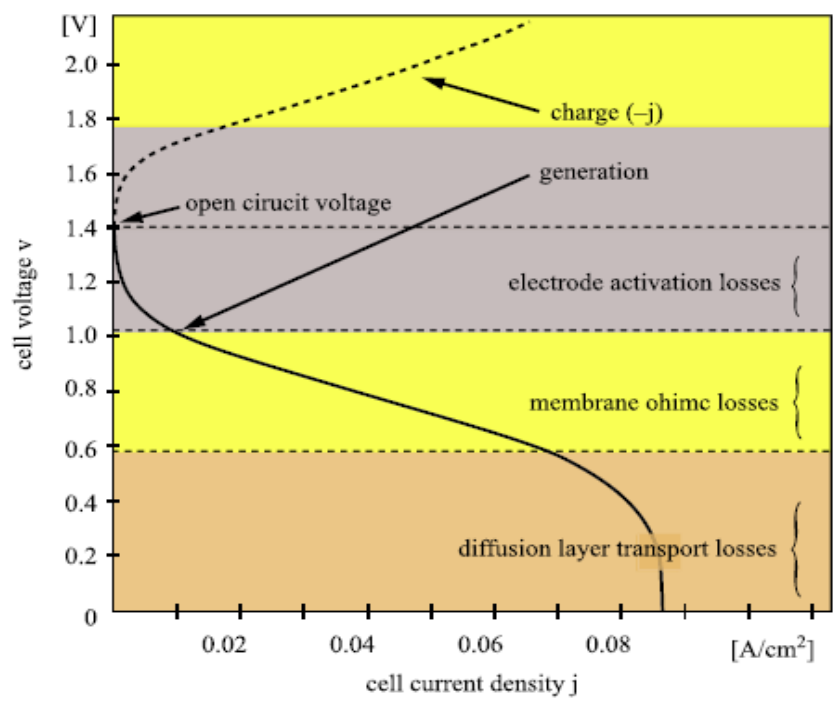

Fig. 4: Polarization curveofa RFFC

According to Butler-Volmer's equation these over potentials are related to the cell current density $\mathrm{j}$ as:

$$
j=j_{0}\left[\frac{c_{r}(0, t)}{c_{r}{ }^{*}} \exp \left(\frac{\propto F}{R T} \eta\right)-\frac{c_{r}(0, t)}{c_{r}{ }^{*}} \exp \left(\frac{(1-\propto) F}{R T} \eta\right)\right]
$$

The voltage is higher than Eo in the charge phase, when $\mathrm{j} 0$ and electric power enters the cell, and lower in the generation phase when j40 and electric power is released. The material of choice for the electrode-separating electrolytic membrane is a perfluorosulfonic acid polymer, patented as Nafion by DuPont, capable of allowing ion transport by binding cations to its sulfonic acid sites when adequately hydrated. At mid current density, the internal losses are dominated by the resistive behaviour of the ion conducting membrane.

Since the voltage of a single RFFC cell is around $1.5 \mathrm{~V}$ at its highest, more cells are connected in series and assembled into stacks to achieve higher voltages. Resembling a design typical of fuel cells, bipolar plates are used to connect one cell to the other.

2.5. Optimization of RES using HOMER, INSEL, TRNSYS, ARES, RET Screen: A comprehensive understanding is essential about available hybrid system models and software tools, their features, shortcomings, user need and choice for research studies. The survey also includes these hybrid simulation tools HOMER, INSEL, TRNSYS, ARES, RET Screen. The investigation was carried out in collaboration with tool developers which included five components namely background information, users, tool properties, application, case studies and further information.

2.5.1. HOMER: Hybrid Optimization Model for Electric Renewable (HOMER) is most widely used, freely available and user-friendly software. The software is suitable for carrying out quick feasibility, optimization and sensitivity analysis in several possible system configurations. The National Renewable Energy Laboratory (NREL), USA has developed HOMER for both on-grid and off-grid systems in 1993.

HOMER uses inputs like various technology options, component costs, resource availability, and manufacturers' data to simulate different system configurations and generates results as a list of available configurations sorted by net present cost. The basic diagram of HOMER software tool is shown in Fig. 5 


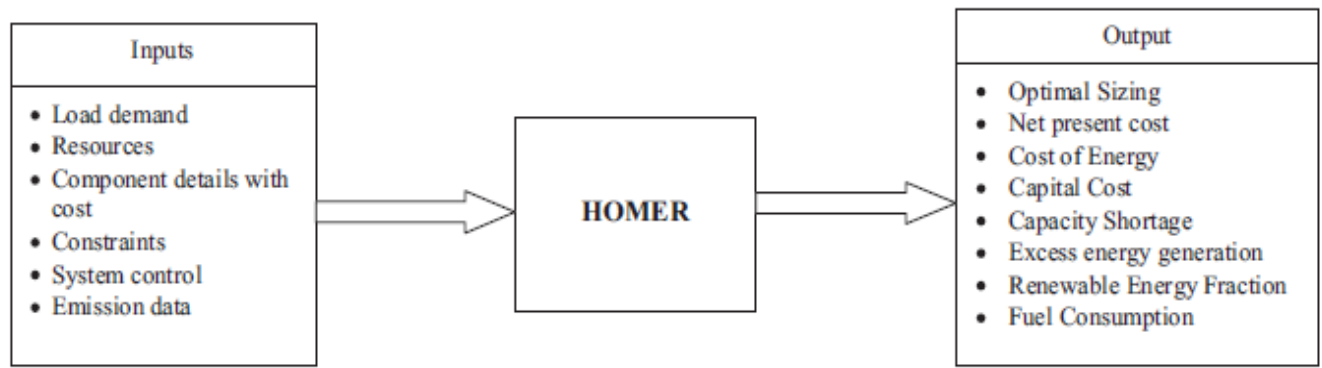

Fig. 5: Schematic representation of HOMER

2.5.2. INSEL: A general-purpose graphical modelling language INSEL (Integrated Simulation Environment Language) was developed by the University of Oldenburg, Germany which allows the users to make a structure with the help of its library with a specified execution time. This simulation software has the flexibility of creating system models and configurations for planning and monitoring of electrical and thermal energy systems. This software has its database of meteorological parameters of almost 2000 locations worldwide, photovoltaic systems, thermal systems and other devices hourly irradiance, temperature, humidity and wind speed data can be generated by using this software from monthly mean values for any given location and orientation. Solar thermal systems also can simulate using INSEL. The software is under continuous improvement during the last two decades. The last updated version of INSEL is INSEL 8.The schematic representation of INSEL is shown in Fig. 6

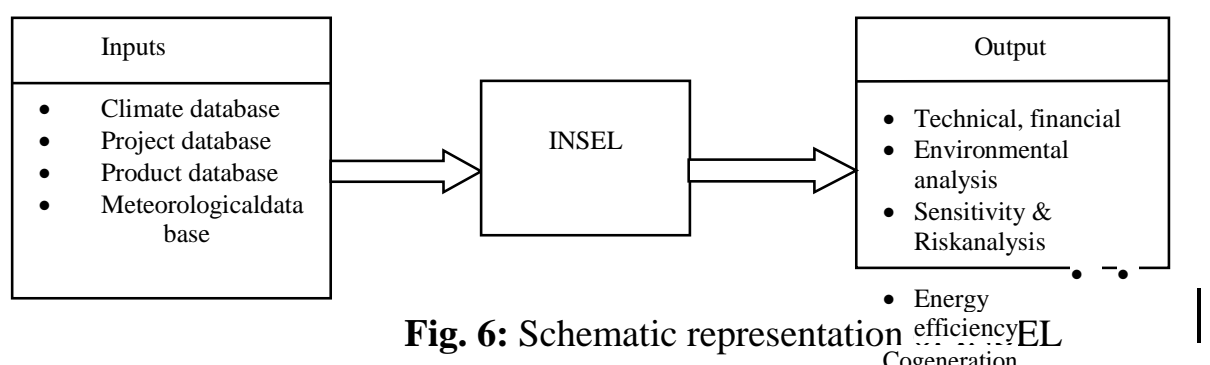

2.5.3. TRNSYS: In the 1975 University of Wisconsin and University of Colorado (USA) jointly developed energy system simulation software named Transient Energy System Simulation Program (TRNSYS). TRNSYS was initially developed for thermal systems simulation, but with a span of more than 35 years, this software has upgraded and changed its features.

It has now included photovoltaic, thermal solar and other systems and has become a hybrid simulator. This simulation program is developed for modelling of thermal energy flows based on FORTRAN code. This is exceptionally flexible graphically based software used to simulate transient system behaviour with two parts one is kernel and another is the library. Kernel processes the input file and solves the system with various techniques and determines convergence whereas, the second part library includes various models which can also modified by user.

TRNSYS does not provide optimization facilities, but it carries out simulation with precision, graphics and other details. TRNSYS is used in solar systems (solar thermal and photovoltaic systems), low energy buildings and HVAC systems, renewable energy systems, cogeneration, fuel cells. The latest version of TRNSYS is 18.The schematic representation of TRNSYS is shown in Fig. 7 


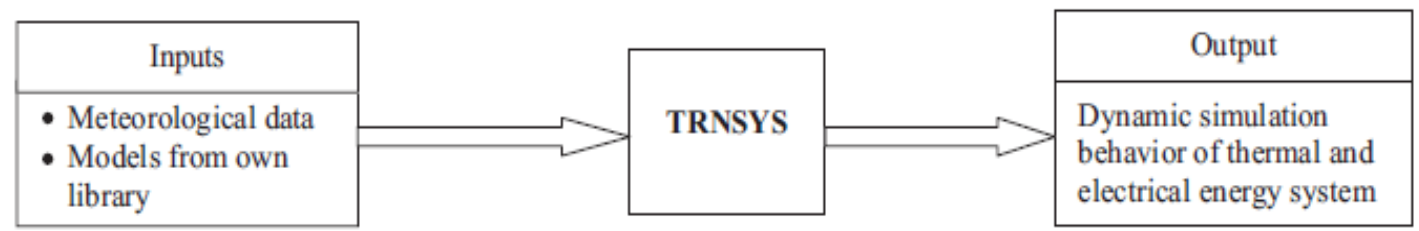

Fig. 7: Schematic representation of TRNSYS

2.5.4. ARES: Autonomous Renewable Energy Systems (ARES) is a program developed at the Cardiff school of engineering, University of Wales, UK for simulation of PV-wind-battery systems. This software can calculate the system loss of load probability and system autonomy through the prediction of the storage battery voltage if input load and basic weather profile are given. The software has two versions ARES-I and the modified version of ARES-I by Morgan is known as ARES-II. ARES-I, consisted of subroutine program in the following order: weather statistics, photovoltaic generation, wind generation, load calculation, combined source and load current, battery voltage subroutine, controller action, and presentation of results. ARES-II required load and basic weather profile inputs and calculates the system loss of load probability and system autonomy using storage battery voltage prediction.The schematic representation of ARES is shown in Fig. 8

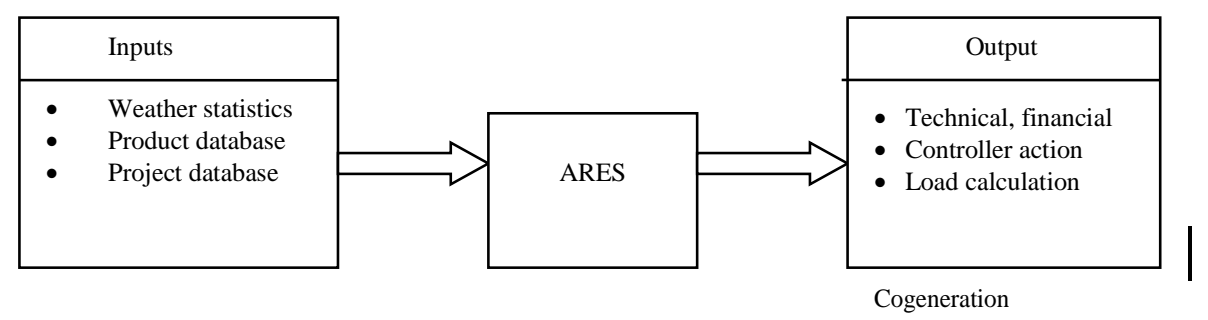

Fig. 8: Schematic representation of ARES

2.5.5 RET Screen: RET Screen is feasibility study tool and is freely downloadable software developed by Ministry of Natural Resources, $\mathrm{Canada}^{[8]}$.The figure 9, gives a schematic representation of RET Screen software. RET Screen was released in 1998 for on-grid applications. RET Screen PV model also covers off-grid PV applications and include stand-alone, hybrid and water pumping systems also. It also provides a link to NASA climate database. The latest version of RET Screen Expert released on September 19th, 2016. RET Screen has used for the analysis of different types of energy efficient and renewable technologies (RETS) covering mainly energy production, life-cycle costs and greenhouse gas emission reduction.

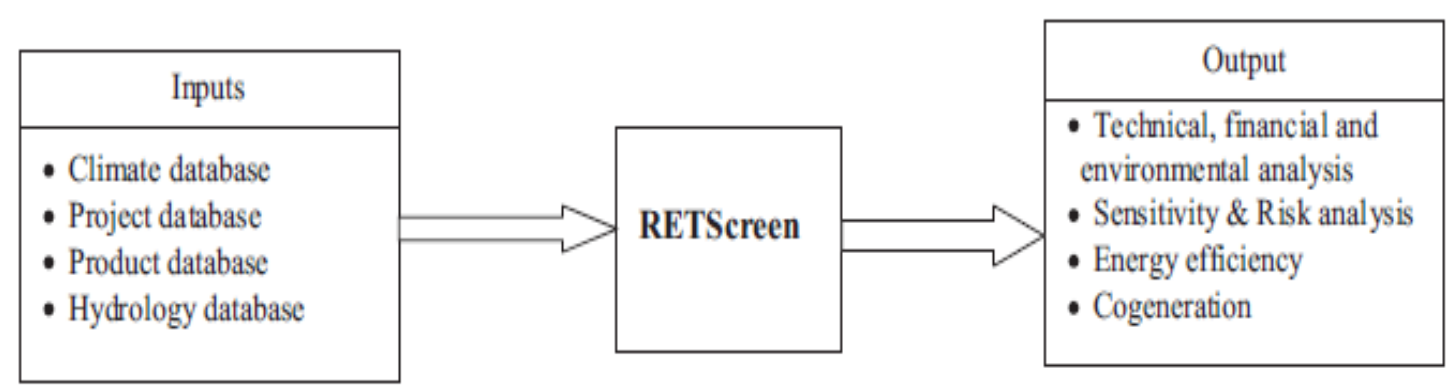

Fig. 9: Schematic representation of RET Screen 
2.3. Research studies using hybrid system software tools: The hybrid system analysis software tools have been used by a number of researchers worldwide. HOMER is found to be most widely used tool in the research studies followed by RETScreen, TRNSYS, INSEL and ARES.

Table 1: Analysis capabilities of hybrid system software tools

\begin{tabular}{|c|c|c|c|c|c|c|c|c|c|}
\hline TOOLS & $\begin{array}{c}\text { Economical } \\
\text { Analysis }\end{array}$ & $\begin{array}{c}\text { Technical } \\
\text { Analyst }\end{array}$ & $\begin{array}{c}\text { PV } \\
\text { System }\end{array}$ & $\begin{array}{c}\text { Wind } \\
\text { System }\end{array}$ & $\begin{array}{c}\text { Generator } \\
\text { set }\end{array}$ & $\begin{array}{c}\text { Storage } \\
\text { device }\end{array}$ & $\begin{array}{c}\text { Bio- } \\
\text { energy }\end{array}$ & $\begin{array}{c}\text { Hydro } \\
\text { energy }\end{array}$ & $\begin{array}{c}\text { Thermal } \\
\text { System }\end{array}$ \\
\hline RETScreen & $\checkmark$ & $\checkmark$ & $\checkmark$ & $\checkmark$ & - & $\checkmark$ & - & - & - \\
\hline INSEL & - & $\checkmark$ & $\checkmark$ & $\checkmark$ & $\checkmark$ & $\checkmark$ & - & - & $\checkmark$ \\
\hline TRNSYS & $\checkmark$ & $\checkmark$ & $\checkmark$ & $\checkmark$ & $\checkmark$ & $\checkmark$ & - & - & $\checkmark$ \\
\hline HOMER & $\checkmark$ & $\checkmark$ & $\checkmark$ & $\checkmark$ & $\checkmark$ & $\checkmark$ & $\checkmark$ & $\checkmark$ & - \\
\hline ARES & - & $\checkmark$ & $\checkmark$ & $\checkmark$ & $\checkmark$ & $\checkmark$ & - & - & - \\
\hline HYBRID2 & - & $\checkmark$ & $\checkmark$ & $\checkmark$ & $\checkmark$ & $\checkmark$ & - & - & $\checkmark$ \\
\hline iHOGA & $\checkmark$ & $\checkmark$ & $\checkmark$ & $\checkmark$ & $\checkmark$ & $\checkmark$ & - & $\checkmark$ & - \\
\hline HYBRIDS & - & $\checkmark$ & $\checkmark$ & - & - & $\checkmark$ & - & - & - \\
\hline RAPSIM & - & $\checkmark$ & $\checkmark$ & $\checkmark$ & $\checkmark$ & $\checkmark$ & - & - & - \\
\hline SOMES & $\checkmark$ & $\checkmark$ & $\checkmark$ & $\checkmark$ & - & $\checkmark$ & - & - & - \\
\hline SOLSIM & $\checkmark$ & $\checkmark$ & $\checkmark$ & $\checkmark$ & $\checkmark$ & $\checkmark$ & $\checkmark$ & - & - \\
\hline IPSYS & - & $\checkmark$ & $\checkmark$ & $\checkmark$ & $\checkmark$ & $\checkmark$ & - & $\checkmark$ & - \\
\hline
\end{tabular}

2.3.1. Comparison of HOMER and RET Screen Softwares: A comparison of two widely used software HOMER and RET Screen is shown in this section. HOMER and RET Screen have some similarities like both take only global irradiation as input, and synthesize the diffuse irradiation internally ${ }^{[8]}$

RET Screen uses Microsoft Excel to perform analysis based upon monthly statistical averages with lots of meteorological and geographical inbuilt information. RET Screen uses Evans electrical model with month-averaged ambient temperature and the PV panel material characteristics data to calculate power output, whereas HOMER uses basic relation model. The main difference between HOMER and RET Screen is shown in Table 2.

The main strength of RET Screen is the detailed economic analysis and robust database whereas HOMER is better suited for a more advanced user and can handle a much denser simulation which makes HOMER one of the most widely used hybrid system optimization tool. 
Table 2: Trade-off inference between HOMER and RET Screen

\begin{tabular}{|c|c|c|}
\hline Parameters & HOMER & RET Screen \\
\hline Data import & Time series data import option & No option for time series data \\
\hline Temperature effect & $\begin{array}{l}\text { Temperature effect on solar PV system } \\
\text { is included }\end{array}$ & $\begin{array}{l}\text { Temperature effect is not } \\
\text { included }\end{array}$ \\
\hline Financial evaluation & $\begin{array}{l}\text { Detailed financial analysis like RET } \\
\text { Screen cannot be done by HOMER. } \\
\text { But it calculates Net Present Cost, Cost } \\
\text { of Energy, Operating Cost and Initial } \\
\text { Cost }\end{array}$ & $\begin{array}{l}\text { Detailed analysis like cost } \\
\text { analysis, financial analysis, } \\
\text { risk analysis and emission } \\
\text { analysis and it is the strength of } \\
\text { this software }\end{array}$ \\
\hline Excess electricity production & Calculate excess electricity generated & $\begin{array}{l}\text { No option to calculate excess } \\
\text { electricity generated }\end{array}$ \\
\hline $\begin{array}{l}\text { Performance evaluation } \\
\text { capability }\end{array}$ & Hourly basis data handling capability & $\begin{array}{l}\text { Evaluated performance based } \\
\text { upon monthly averages }\end{array}$ \\
\hline Capacity Shortage option & $\begin{array}{l}\text { Maximum annual capacity shortage } \\
\text { can be included }\end{array}$ & No option for capacity shortage \\
\hline Data base & $\begin{array}{l}\text { Much more way of data input although } \\
\text { it has some database }\end{array}$ & $\begin{array}{l}\text { It has its own database and less } \\
\text { data input way }\end{array}$ \\
\hline Computational time & $\begin{array}{l}\text { HOMER shows the computational } \\
\text { time taken to simulate a study }\end{array}$ & $\begin{array}{l}\text { RET Screen do not show the } \\
\text { computational time taken as it is } \\
\text { excel based software. }\end{array}$ \\
\hline
\end{tabular}

\section{RESULTS \& DISCUSSIONS}

The proposed system along with $15 \mathrm{~kW}$ of fuel cell connected to Standalone hybrid renewable systems and the respective performance of the fuel cell is obtained using Matlab/Simulink.

The proposed control strategy has been experimentally implanted and the practical results are made with a trade-off to those obtained by simulation under the same metrological conditions, showing the effectiveness of the proposed hybrid system ${ }^{[9]}$.

The starting transient response of the cell voltage of fuel cell at different load current is presented in Fig.10. It was inferred that the settling time diminishes as the load current settles to a higher value. At rated load, the cell voltage is increased to $1.229 \mathrm{~V}$ and goes down to a steady state of $0.58 \mathrm{~V}$ in just 0.015 seconds. 


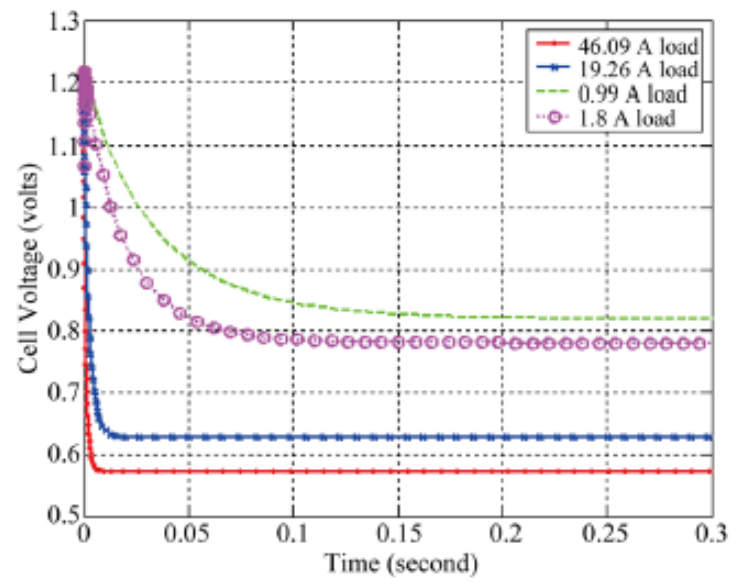

Fig. 10: Cell voltage transient behaviour of fuel cell

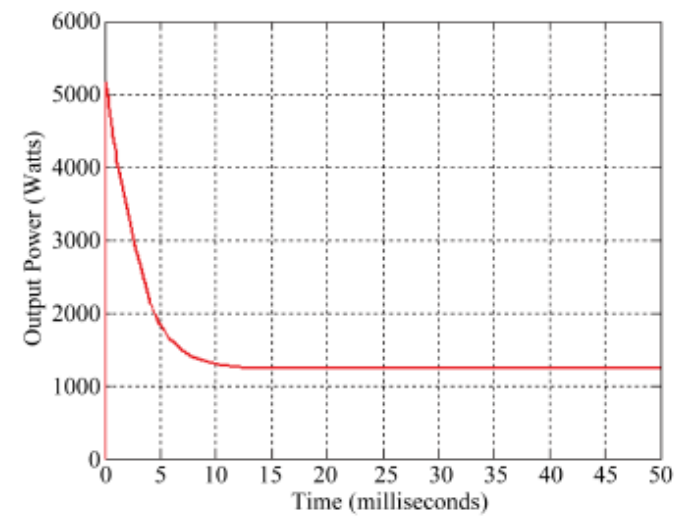

Fig.11: Load voltage and current transient behavior of a $15 \mathrm{~kW}$ fuel cell

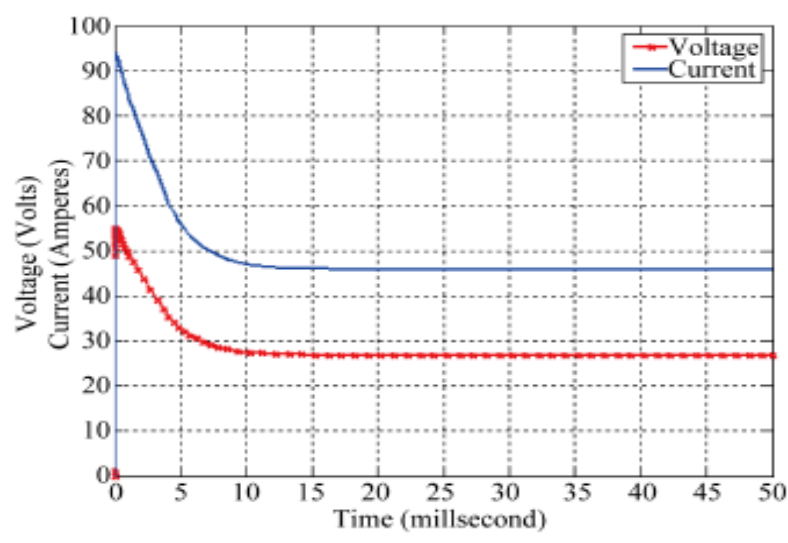

Fig.12: Power output transient behavior of a $15 \mathrm{~kW}$ fuel cell

The transient output response of the load voltage, current and power of a $15 \mathrm{~kW}$ fuel cell is presented in Figures 11 and 12. It was inferred that at rated load the current reaches to $95 \mathrm{Amps}$ and it stabilizes to $45.84 \mathrm{~A}$ while the voltage goes up to $55 \mathrm{~V}$ and stabilizes to 26.81 volts. 


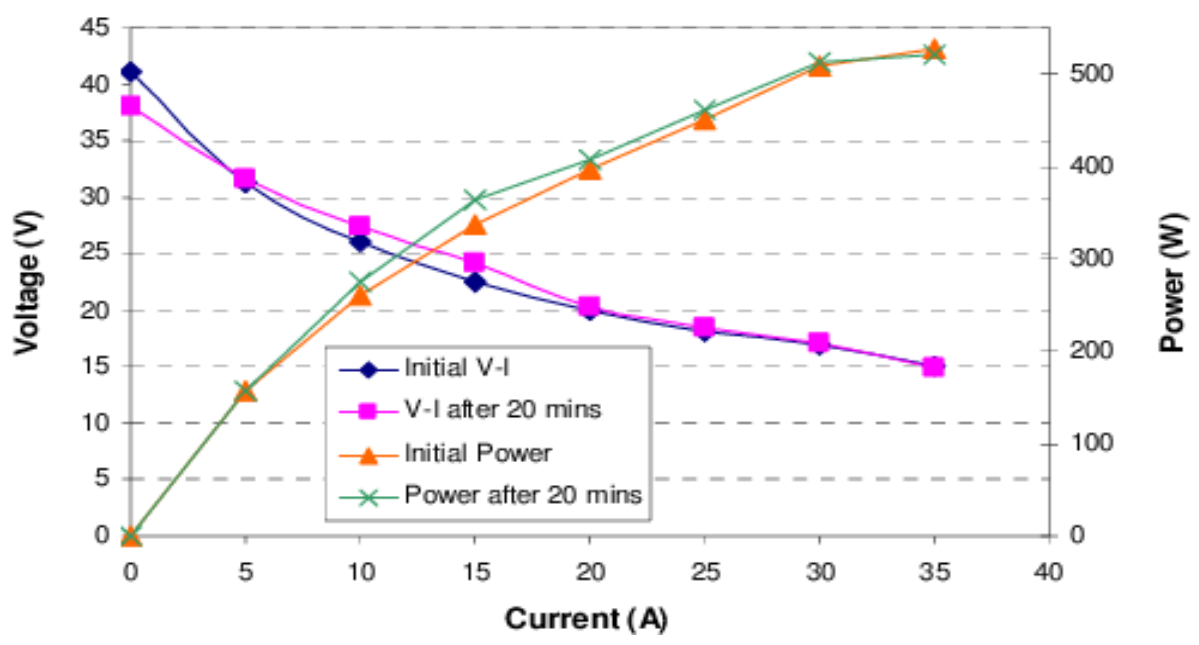

Fig.13: Voltage, current and power behavior of a $15 \mathrm{~kW}$ fuel cell

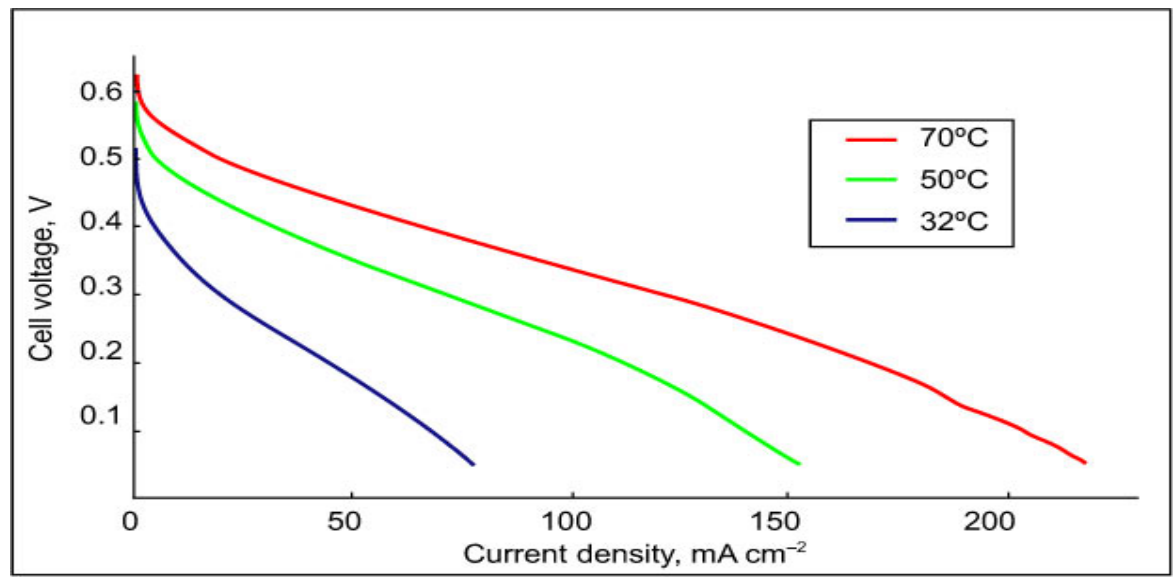

Fig. 14: Voltage, current under different temperature conditions of a $15 \mathrm{~kW}$ fuel cell

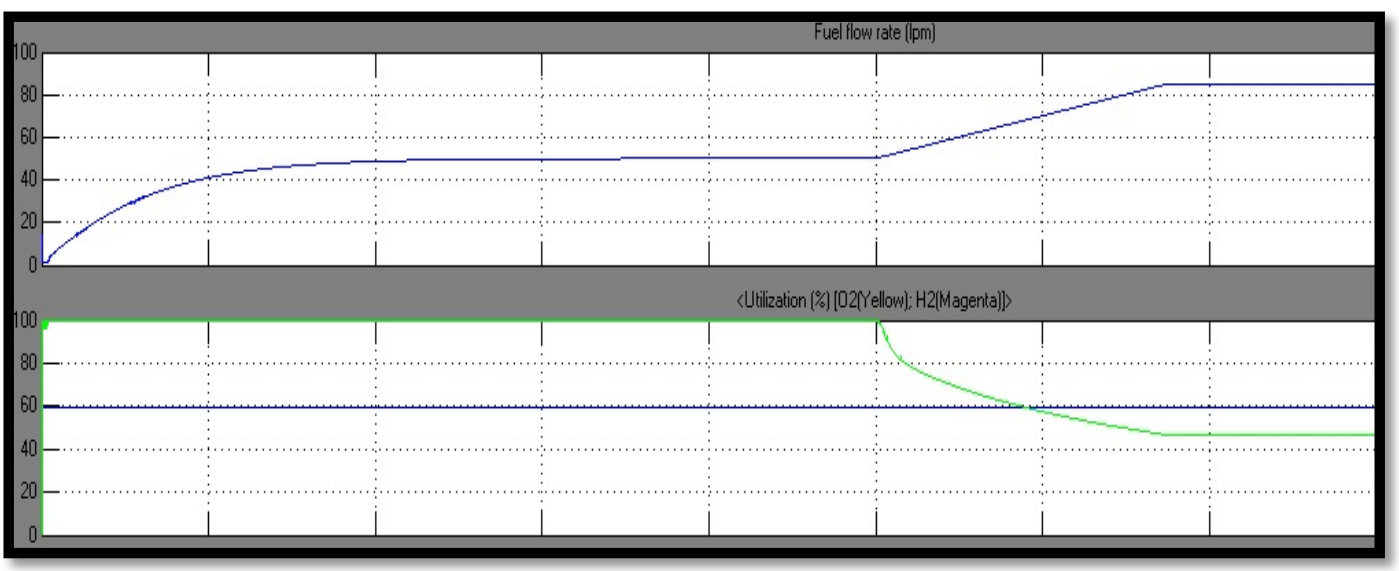

Fig. 15: Stack consumption and stack efficiency of a $15 \mathrm{~kW}$ fuel cell 


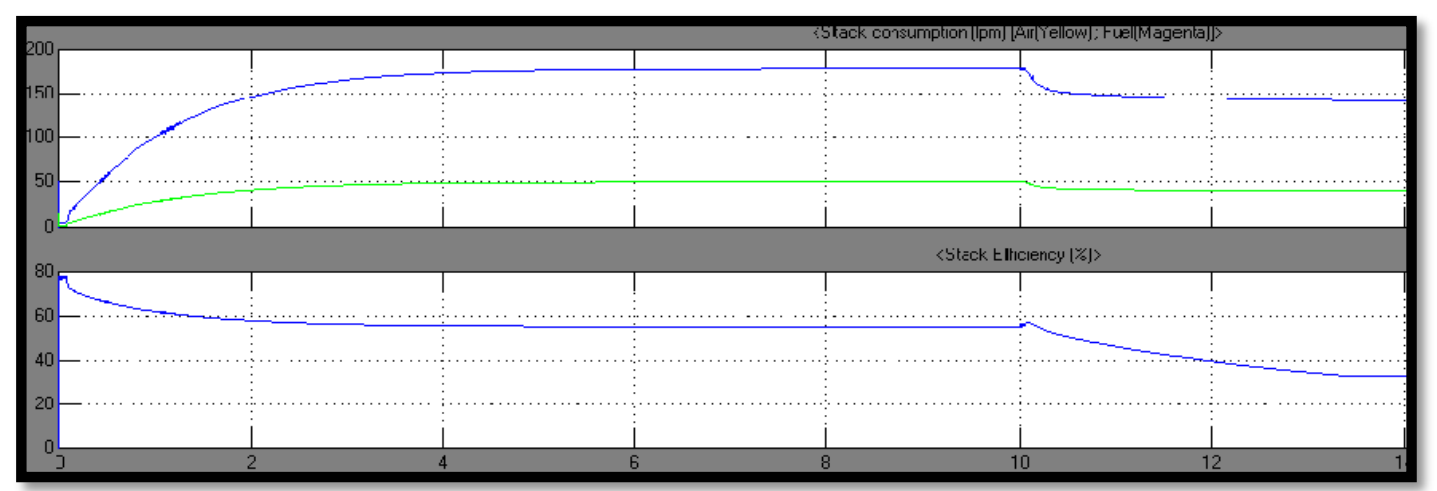

Fig. 16: Fuel flow rate and utilization of a $15 \mathrm{~kW}$ fuel cell

Table 3: Trade-off inference of optimization of Hybrid Renewable Energy Sources

\begin{tabular}{|l|l|}
\hline Softwares & Analysis type \\
\hline RET Screen & Financial, environmental analysis \\
\hline INSEL & Planning, monitoring of electrical and thermal energy systems \\
\hline TRNSYS & Simulate transient system behaviour \\
\hline HOMER & $\begin{array}{l}\text { Technical analysis; economic analysis; emission analysis: } \\
\text { environmental analysis }\end{array}$ \\
\hline ARES & Technical analysis; economic analysis \\
\hline HYBRID2 & Technical analysis; economic analysis \\
\hline iHOGA & Multi or mono objective optimization using genetic algorithm \\
\hline HYBRIDS & Technical analysis \\
\hline RAPSIM & Simulates performance of a range of hybrid power systems \\
\hline SOMES & Technical analysis; economic analysis \\
\hline SOLSIM & Technical analysis; economic analysis \\
\hline IPSYS & Simulation with control strategies \\
\hline
\end{tabular}

\section{CONCLUSION}

The conventional optimization of energy storage technologies involves complex mathematical computations, transformations, multiple PI controllers, and the input voltage sensing increases the cost and complexity of the system. To overcome these bottlenecks, it has been concluded, from the trade-off inference, that Hybrid Optimization Model for Electric Renewable (HOMER) software is used for optimizing the climatic forecasting, which paves the way for nurturing new applications. Also, it evident that the Red-Ox Flow fuel Cell is instrumental in ideally interfacing the fuel cell and hydrogen. This system also opens new avenues in Distributed Generation System (DGS), which improves the robustness of Hybrid Renewable Energy Sources. This work provides a trade-off inference among different RES software tools, and it serves as a guideline to the user to use which software tool is to be used for a specific application. 


\section{REFERENCES}

1. R.Ramakumar,I.Abouzahr, K.Krishnan, K.Ashenayi, "Design scenarios for integrated renewable energy systems", IEEE Transactions on Energy Conversion, 1995, 10,4,736-746 .

2. AnuragChauhan, R.P.Saini, "Renewable energy based power generation for standalone applications:Review”, IEEE, 2013.

3. SunandSinha, S.S.Chandel, "Review of software tools for hybrid renewable energy systems", Renewable and Sustainable Energy Reviews, 2014, 32,192-205.

4. E.S.Gavanidou, A.G.Bakirtzis, "Design of a standalone system with renewable energy sources using trade off methods", IEEE Transactions on Energy Conversion, 1992, 7, 1, 4248.

5. Sandro Skoda, Eric Robalinho, André L. R. Paulino, Edgar F. Cunha, Marcelo Linardi, "Modeling of Liquid Water Distribution at Cathode Gas Flow Channels in Proton Exchange Membrane Fuel Cell - PEMFC", Excerpt from the proceedings of the 2013 COSMOL Conference in Rotterdam.

6. W. Smith, "The role of fuel cells in energy storage", Journal of Power Sources, 2000, 86, 7483.

7. Sourabhnamdev, Ankit Gupta, "Feasibility Analysis of PV System with Dual Axis Mode For Electrification", International Journal of Advanced Technology for Science \& Engineering Research. 2017, 2, 4, 17-25.

8. G.Ganesan, Dr.R.Sagayaraj\&Dr.A.Nazar Ali, Investigations on Review of Software Tools for the Integration of Renewable Energy Systems for Sustainable Energy Development, International Journal for Research in Engineering Application \& Management (IJREAM), 2018, 4, 04, 705-710.

9. Dr. R.Sagayaraj \& S.Karthikeyan, Optimizing Fuel Cells in Energy Storage Technologies for Renewable Energy Sources, International Journal of Engineering Research and Applications,2018, 8, 6, 39-43.

\section{Corresponding author: Dr. P.Jenopaul}

${ }^{5}$ Professor, Department of Electrical \& Electronics Engineering,AdiShankara Institute of Engineering and Technology, kalady, Kerala, India.

Online date of publication: 10.06.2021 